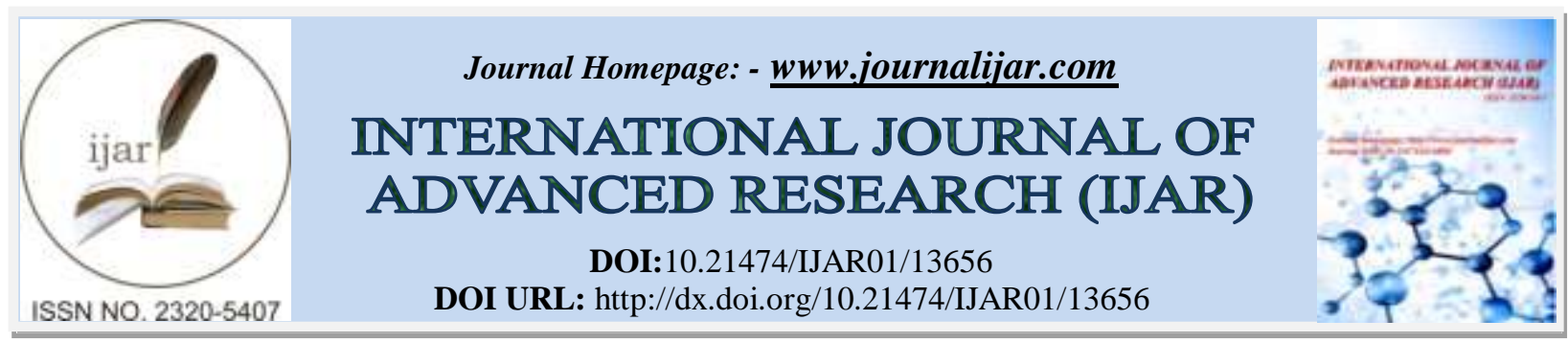

RESEARCH ARTICLE

\title{
The Role of Cooperative Instructional Strategies on Student's Commitment to Physics in Rural Communities of Kogi State
}

Nwaba A. Abraham and Musa Sunday

Department of Physics Kogi State College of Education, Ankpa.

\section{Manuscript Info}

Manuscript History

Received: 31 August 2021

Final Accepted: 30 September 2021

Published: October 2021

Key words:-

CIS, Commitment, Physics, Rural Students

\begin{abstract}
Physics has continued to generate favorable commendation in the educational landscape of every society in the modern-day world. However, the concern about the increasing decline in student's performance and the growing purported difficulties associated with the subject has continued to attract research attention. There are intimations that secondary school students in rural communities are more likely to commit less effort to science subjects. Thus, the primary purpose of this study was to investigate cooperative instructional strategy as a wellresearched teaching method that could also improve student's commitment to physics. Two hundred and nineteen secondary school students in the rural communities in Kogi State, Nigeria, enrolled in the science classes participated in the study. A quasi-experimental pre-test, post-test research design was employed for the study. The participants were grouped into two different groups for the pre-test and post-test analyses. The experimental group was exposed to the cooperative instructional teaching method, while the control group was taught conventionally. An independent-samples t-test was performed to determine differences between the observed and the control groups on a commitment to physics in the post-test study with a statistically significant $M D=10.85, \mathrm{t}(117)=20.026, \mathrm{p}=.001$. It was concluded that cooperative instructional strategy enhances student's commitment to physics. The study recommends robust training of teachers on the use of collaborative instructional strategies.
\end{abstract}

Copy Right, IJAR, 2021, All rights reserved.

\section{Introduction:-}

The contemporary society is keen on developing education standards capable of equipping learners with skills commensurate with modern society (Ince, 2018). The world has transformed into a culture of growing innovations which requires a robust transformation in the objective of the educational system of every society. Thus, studies (Bao \& Koenig, 2019; Ludwig et al., 2017; Qablan et al., 2019) have advocated for learning encompassing creativity and skills. Teaching and learning relating to sciences geared towards developing high-end skills encompassing creative reasoning and problem-solving are imperative in nation-building (Ankeli, 2019; Clement et al., 2017; Okwuoyibo, 2012; Olufunke, 2012).Researchers (e.g., Aderonmu \& Obafemi, 2015; Fuwape et al., 2019; Kola, 2013; Odu, 2020) noted that science and technology are the fundamental bases for advancing and modernization of any nation. Thus, achieving the universal mandate in technological advances demands more effort in exposing learners to the basic concepts in scientific studies. Perhaps, Scholars (e.g., Adolphus, 2019; Kola, 2013; 
Ogunjuyigbe et al., 2006; Sambo et al., 2014)contend that the government of Nigeria, through the national policy on education, emphasized the relevance associated with investing in science education. Hence, the attention accorded to the global trends in science, technology, engineering, and mathematics (STEM) education. Accordingly, one of the important subjects within the Nigerian educational system that is imperative in achieving the objective of STEM education is physics.

Faridi et al. (2021), Daramola, and Omosewo (2012) referred to physics as part of the science subjects that focus on the phenomenon of energy and matter. Physics deals with the structure of matter, including the interaction between the fundamental bases of the physical entity. Nigeria's educational system considers physics an essential science subject in the school curricular (Ojediran, 2016; Onah \& Ugwu, 2010; Daramola \& Omosewo, 2012; Mobolaji et al., 2017; Mbamara \& Eya, 2015). The subject engages the learners in problem-solving tasks (Santyasa et al., 2020) and provides the students with basic literacy in physics for functional inclusion in society. Also, it equips the learners with essential scientific skills and attitudes towards the technological demands of the world. The link between physics and scientific innovations is well highlighted in the literature (Bortfeld \& Jeraj, 2011; Bunyamin et al., 2020; Chu, 2020; Moraga-Calderón et al., 2020; Ukoh \& Onifade, 2020). However, the place of physics education in Nigeria demands continued attention.

Over the years, students' performance in physics has persistently remained poor in most schools in Nigeria. It is purported to be a complex subject by many students, especially at the secondary school level. The subject has been poorly reported in various examinations, including the West African Examination Council (WAEC) and other national exams in Nigeria. Perhaps, the poor performance in physics has attracted extensive research attention worldwide(Coffie et al., 2020; Ebong, 2021; Falode \& Ajala, 2014; Folashade \& Akinbobola, 2009; Madu \& Udoh, 2016; Onah \& Ugwu, 2010). Consequently, numerous factors, including an unconducive learning environment, unguided teaching method, poor teacher's knowledge, cognitive styles, peer and parental influence, and other demographic variables, have been associated with students' poor physics performance(Erdemir, 2009).

Research has suggested that students from rural communities perform lower in science subjects than their urban counterparts(Umar \& Samuel, 2018). Thus, Abamba (2021)opined that schools within rural areas are more challenged with inadequate instructors, practical laboratories, and functional equipment in Nigeria. Accordingly, (Hu 2003)contends that students from the rural setting tend to commit less attention and exhibit low aspiration and motivation towards academics. However, intimations suggest that the low performance of students in physics is more pronounced in rural areas. For example, (Salmiza 2014)found a significant difference between urban and rural students' motivation towards learning physics. The present study is focused on improving rural student's commitment to physics using cooperative instructional strategies.

Commitment is an essential determinant of success in any aspect of human endeavour(Babajide, 2010). Commitment to physics refers to a student's overall enthusiasm to dedicate added time, energy, work, interest, affection, and values to learn physics. Hence, it requires a positive attitude and favourable perception of the subject. There is a growing concern that the poor learning infrastructures that characterize the rural communities in Kogi state are linked to the observed lack of student's commitment to studies. However, there appears to be a consensus among science education scholars that cooperative learning is pivotal to learners' development of science knowledge(Chatila \& Husseiny, 2016; Columbano, 2019; Mahrani et al., 2018).

The cooperative instructional approach entails a learning method that requires instructors to group learners according to their capabilities using numerous instructional activities to expand their knowledge of the subject. In this regard, members in a group are anticipated to work together to yield a cooperative outcome. Prata et al. (2019) had noted that the approach reflects an indispensable tool for teaching school engagement. Additionally, Ifamuyiwa and Akinsola (2008) advocated teacher training and adopting cooperative learning approach in the classroom. Others have linked collaborative instructional strategy to increased interest, performance, and attitude (Adebayo \& Judith, 2014; Akinsola \& Ifamuyiwa, 2008; Appiah-Twumasi et al., 2020; Nnorom, 2015; Matazu \& Julius, 2018; Yunusa et al., 2014). However, the link between cooperative instructional strategy and student commitment is lacking in the literature, hence, the current study. The study argued that even when materials and pedagogy are inadequate, other instructional strategies could increase the students' commitment to learning. Thus, the current research aims to answer the question: would cooperative instructional strategies improve rural students' commitment to learning physics. 


\section{Method:-}

One hundred and nineteen students from public and private secondary schools in the Kogi State of Nigeria were recruited as the research participants. The samples comprised males and females between the ages of 12 and 16 enrolled in the science classes in five different schools. Before the commencement of the research, the researcher sought authorization from the relevant heads of the schools. After that, the regular physics teachers were trained as study assistants. They were made conversant with the study procedures and guidelines. Thus, the teachers were instrumental in selecting and preparing the students for the study. However, they were informed that participation in the study was entirely voluntary and that no harm was associated with the investigation. Those who consented were allowed to participate in the study. The study design was quasi-experimental with a pre-test, post-test control group, which means that the participants were assigned to groups. Group (A) experimental and group (B) the control group. Firstly, a pre-test investigation was conducted to determine the student's commitment to physics before the commencement of the main experiment using a developed questionnaire. After that, the primary study commenced with group A (i.e., experimental group) being exposed to the cooperative instructional method and group B receiving teaching via the conventional way. In the post-test study, the questionnaire was readministered to ascertain anydifference regarding commitment to physics between the groups.

\section{Result:-}

Table 1:- Table shows mean and standard deviation scores of the students' commitment to physics in the pre-test study.

\begin{tabular}{llll}
\hline Group & $\mathrm{N}$ & $\mathrm{M}$ & $\mathrm{SD}$ \\
\hline Group A & 68 & 23.18 & 4.18 \\
Group B & 51 & 23.21 & 5.14 \\
MD & & 0.03 & \\
\hline
\end{tabular}

The table shows that $M=23.18, S D=4.18$, and $M=23.21, S D=5.14$ were recorded for the two conditions in the pre-test study. Thus, the table indicates no significant difference in the mean scores of the experimental and the control groups, which means that the group's level of commitment to physics seems equal at $M D=0.03$.

Table 2:- Table showing the mean and standard deviation scores of the students' commitment to physics in the posttest.

\begin{tabular}{llll}
\hline Group & $\mathrm{N}$ & $\mathrm{M}$ & $\mathrm{SD}$ \\
\hline Group A & 68 & 42.01 & 4.93 \\
Group B & 51 & 31.16 & 4.47 \\
MD & & 10.85 & \\
\hline
\end{tabular}

The above table shows that $M=42.01, S D=4.93$, and $M=31.16, S D=4.47$ was obtained for the two conditions following the post-test study. The data revealed $M D=10.85$ for the groups with the experimental scoring higher than the control group. Thus, it means ahigh mean score for the experimental group $(M=42.01)$ compared to the control group $(M=31.16)$. The standard deviation scores indicated a higher $S D=4.93$ for the experimental group and a decreased $S D=4.47$ for the control group. Therefore, it is assumed that the mean indicates an affirmation that the experimental group's commitment to physics increased following the introduction of cooperative instructional strategy.

Table 3:- Table showing the t-test comparison of the differences in commitment to physics for the two groups.

\begin{tabular}{lllllll}
\hline Source of variation & $\mathrm{N}$ & $\mathrm{M}$ & $\mathrm{SD}$ & $\mathrm{df}$ & $t$ & Sig \\
\hline Group A & 68 & 42.01 & 4.93 & & & \\
Group B & 51 & 31.16 & 4.47 & 117 & 20.026 & 000 \\
\hline
\end{tabular}

An independent-samples t-test was run to answer the research question on whether cooperative instructional strategy would improve rural student's commitment to physics. The analysis established a statistically significant difference between the two groups on commitment to physics in the post-test study $M D=10.85, \mathrm{t}(117)=20.026, \mathrm{p}=.001$.

\section{Discussion:-}

The primary purpose of the current study was to determine whether the cooperative instructional strategy would improve commitment to physics among rural secondary school students in Kogi state. Thus, the study seeks to 
investigate if there would be differences between two groups of students taught with cooperative instructional strategy and the conventional method, respectively. Following the data analysis performed with the independent ttest analysis, the assumption that a collaborative instructional approach will improve the rural student's commitment to physics was affirmed. This is due to the observed statistical outcome of the post-test mean score difference of $M D$ $=10.85$ and a t-test report $\mathrm{t}(117)=20.026, \mathrm{p}=.001$, indicating a statistically significant difference between the two groups. In other words, the result demonstrates that employing a cooperative learning approach in rural secondary schools could be a pathway to improving student's commitment to physics. This result could be because the students exposed to the cooperative instructional method (experimental group) interacted with each other, seeking more information, sharing ideas, and making decisions together compared to the students in the conventional classroom (control group). This opportunity might foster learning and improves the overall instructional environment in the school. The finding is consistent with previous studies (e.g., Appiah-Twumasi et al., 2020; Sa'adu Matazu \& Julius, 2018; Yunusa et al., 2014). For example, a similar study has previously reported that cooperative instructional strategy significantly boosted students' achievement in organic chemistry than the lecture method(AgwuUdu, 2018).In another related study, Aluko (2008) emphasized that adopting a cooperative instructional strategy promotes performance. More so, the literature indicates that cooperative instructional methods have been utilized to examine student's learning outcomes in various domains(Esan, 2015; Inuwa et al., 2017; Leam \& Studies, 2009). Perhaps, the central characteristics of all studies relating to cooperative learning reflect the approach as more effective than the traditional face-to-face method. Thus, the present result supports the existing literature advocating for full integration of the cooperative learning approach in secondary schools.

\section{Conclusion:-}

The study aimed to investigate cooperative instructional strategy as a learning approach that could improve the commitment of rural students to physics. Thus, the study established a significant difference between the experimental and the control group on the commitment to physics. Thereby, it was concluded that cooperative instructional strategy is an indispensable learning approach that could improve the rural student's responsibility to physics. The study implies that if teachers continually employ this method in the classroom, especially in rural communities, the students will have more opportunities to express their capabilities with peers in their styles. The technique reflects a social learning approach that allows the least committed student to input and adapts easily to the concept. Thereby, this method could improve the overall commitment of the youngsters. Although, the size of the sample reflects a limitation that might affect the generalization of the result. However, the study broadened our understanding of the possibility of improving rural student's commitment to physics and other subjects in general. Therefore, the study recommends robust training of teachers in rural communities on cooperative learning methods.

\section{References:-}

1. Abamba, I. (2021). The effects of School location on students' academic achievement in senior secondary physics based on the 5E learning cycle in Delta State, Nigeria. LUMAT: International Journal on Math, Science and Technology Education, 9(1). https://doi.org/10.31129/lumat.9.1.1371

2. Adebayo, A. S., \& Judith, K. (2014). Comparative study of the effectiveness of cooperative learning strategy and traditional instructional method in the physics classroom: a case of Chibotegirls' secondary school, Kitwe District, Zambia. European Journal of Educational Sciences, 01(01). https://doi.org/10.19044/ejes.v1no1a4

3. Aderonmu, T. S. B., \& Obafemi, D. T. A. (2015). Ordeals of Physics Instruction in Nigerian Secondary Schools: Way Forward for the Attainment of Global Competitiveness. Journal of Education and Practice, 6(20).

4. Adolphus, T. (2019). The Aims and Purposes of Science Education: Social-Scientific Issues in the Science Curriculum in Nigeria. In American Research Journal of Humanities Social Science (ARJHSS)R) 2019 ARJHSS Journal. www.arjhss.com

5. AgwuUdu, D. (2018). Comparative effects of individualized and cooperative learning instructional strategies on senior secondary school students' academic achievement in organic chemistry. Electronic Journal of Science Education, 22(2).

6. Akinsola, M. K., \& Ifamuyiwa, S. A. (2008). Effect of two programmed instructional strategies on senior secondary school students' mathematical achievement. African Journal of Research in Mathematics, Science and Technology Education, 12(2). https://doi.org/10.1080/10288457.2008.10740636

7. Aluko, K. (2008). Teaching Chemistry in Secondary Schools: A Case for Cooperative Instructional Strategy. Ethiopian Journal of Education and Sciences, 3(2). https://doi.org/10.4314/ejesc.v3i2.42005

8. Ankeli, G. O. (2019). Scientific Infrastructure: A Necessary Tool for National Security and Development in Nigeria. In World Journal of Innovation and Modern Technology (Vol. 3, Issue 1). www.iiardpub.org 
9. Appiah-Twumasi, E., Antwi, V., Kwesi Anderson, I., \& Sakyi-Hagan, N. (2020). Comparative Effect of Cooperative Learning on Students' Performance in Mechanics Concepts: A Case of Two Secondary Schools in Berekum Municipality, Ghana. East African Journal of Education and Social Sciences, 1(1). https://doi.org/10.46606/eajess2020v01i01.0015

10. Babajide, V. F. T. (2010). Fostering the Development of Practical Skills among Secondary School Physics Students: Implications for Science Teaching. International Journal of Contemporary Issues in Education. (Special Edition, 2.

11. Bao, L., \& Koenig, K. (2019). Physics education research for 21st-century learning. Disciplinary and Interdisciplinary Science Education Research, 1(1). https://doi.org/10.1186/s43031-019-0007-8

12. Bortfeld, T., \& Jeraj, R. (2011). The physical basis and future of radiation therapy. In British Journal of Radiology (Vol. 84, Issue 1002). https://doi.org/10.1259/bjr/86221320

13. Bunyamin, M. A. H., Talib, C. A., Ahmad, N. J., Ibrahim, N. H., \& Surif, J. (2020). Current teaching practice of physics teachers and implications for integrated STEM education. Universal Journal of Educational Research, 8(5 A). https://doi.org/10.13189/ujer.2020.081903

14. Chatila, H., \& Husseiny, F. Al. (2016). Effect of Cooperative Learning Strategy on Students' Acquisition and Practice of Scientific Skills in Biology. Journal of Education in Science, Environment and Health, 3(1). https://doi.org/10.21891/jeseh.280588

15. Chu, R. (2020). GaN power switches on the rise: Demonstrated benefits and unrealized potentials. In Applied Physics Letters (Vol. 116, Issue 9). https://doi.org/10.1063/1.5133718

16. Clement, I., Bello, M., \& Abdullahi Sunusi, S. (2017). Science Education and Nigeria National Development Effort: The Missing Link. In International Journal of Education and Evaluation (Vol. 3, Issue 5). www.iiardpub.org

17. Coffie, I. S., Frempong, B. B., \& Appiah, E. (2020). Teaching and Learning Physics in Senior High Schools in Ghana: The Challenges and the Way Forward. Advances in Research. https://doi.org/10.9734/air/2020/v21i330192

18. Columbano, M. Q. (2019). Reinforcing students' mathematical skills through cooperative learning strategy. International Journal of Innovative Technology and Exploring Engineering, 8(12). https://doi.org/10.35940/ijitee.L2683.1081219

19. Ebong, S. T. (2021). The influence of parental background on students' academic performance in physics in WASSCE 2000 - 2005. European Journal of Science and Mathematics Education, 3(1). https://doi.org/10.30935/scimath/9419

20. Erdemir, N. (2009). Determining students' attitude towards physics through problem-solving strategy. AsiaPacific Forum on Science Learning and Teaching, 10(2).

21. Esan, F. (2015). Cooperative Problem-Solving Strategy and Students' Learning Outcomes in Algebraic Word Problems: A Nigerian Case. International Journal for Infonomics, 8(1). https://doi.org/10.20533/iji.1742.4712.2015.0116

22. Falode, O. C., \& Ajala, N. A. (2014). Availability and teachers' awareness of the existence of software packages for developing physics instruction for secondary school students in Minna, Nigeria. Chemistry, 23(3).

23. Faridi, H., Tuli, N., Mantri, A., Singh, G., \& Gargrish, S. (2021). A framework utilizes augmented reality to improve the critical thinking ability and learning gain of the students in Physics. Computer Applications in Engineering Education, 29(1). https://doi.org/10.1002/cae.22342

24. Folashade, A., \& Akinbobola, A. O. (2009). Constructivist Problem Based Learning Technique and the Academic Achievement of Physics Students with Low Ability Level in Nigerian Secondary Schools. Eurasian Journal of Physics and Chemistry Education, 1(1).

25. Fuwape, I. A., Ogunjo, S. T., \& Owoola, E. O. (2019). The Dutch FOm/f approach to gender balance in physics AIP Conference. 2109, 50028. https://doi.org/10.1063/1.5110103

26. Hu, S. (2003). Educational aspirations and postsecondary access and choice: Students in urban, suburban, and rural schools compared. Education Policy Analysis Archives, 11. https://doi.org/10.14507/epaa.v11n14.2003

27. Ifamuyiwa, S. A., \& Akinsola, M. K. (2008). Improving senior secondary school students' attitude towards mathematics through self and cooperative-instructional strategies. International Journal of Mathematical Education in Science and Technology, 39(5). https://doi.org/10.1080/00207390801986874

28. Ince, E. (2018). An Overview of Problem-Solving Studies in Physics Education. Journal of Education and Learning, 7(4). https://doi.org/10.5539/jel.v7n4p191

29. Inuwa, U., Abdullah, Z., \& Hassan, H. (2017). Assessing the effect of cooperative learning on financial accounting achievement among secondary school students. International Journal of Instruction, 10(3). https://doi.org/10.12973/iji.2017.1033a 
30. Jacob Kola, A. (2013). Importance of Science Education to National Development and Problems Militating Against Its Development. American Journal of Educational Research, 1(7). https://doi.org/10.12691/education$1-7-2$

31. Leam-, C., \& Studies, S. (2009). Effects of cooperative learning on Junior Secondary School students' knowledge and attitudes to multicultural education concepts in Social Studies. Education, 133(3).

32. Ludwig, P. M., Nagel, J. K., \& Lewis, E. J. (2017). Student learning outcomes from a pilot medical innovations course with nursing, engineering, and undergraduate biology students. International Journal of STEM Education, 4(1). https://doi.org/10.1186/s40594-017-0095-y

33. Madu, B. C., \& Udoh, A. (2016). Exploring Senior Secondary School Two Students' Alternative Conceptions of Current Electricity in Physics in Nigeria. In SAUSSUREA (Vol. 6, Issue 4).

34. Mahrani, Y., Suyanti, R. D., \& Mursid, R. (2018). The Effect of Cooperative Learning on Student's Science Process Skill. https://doi.org/10.2991/aisteel-18.2018.157

35. Moraga-Calderón, T. S., Busiman, H., \& Cramer, J. (2020). The relevance of learning quantum physics from the perspective of the secondary school student: A case study. In arXiv. https://doi.org/10.30935/scimath/9545

36. Nnorom, N. R. (2015). Effect of Cooperative Learning Instructional Strategy on Senior Secondary School Students Achievement in Biology in Anambra State, Nigeria. International Journal for Cross-Disciplinary Subjects in Education, 5(Special 1). https://doi.org/10.20533/ijcdse.2042.6364.2015.0331

37. Odu, K. O. (2020). Human Capital Development in Science and Technology Education: Challenges and New Responsibilities of the Teacher. Contemporary Educational Technology, 2(3). https://doi.org/10.30935/cedtech/6056

38. Ogunjuyigbe, P. O., Ojofeitimi, E. O., \& Akinlo, A. (2006). Science education in Nigeria: An examination of People's Perceptions about female participation in science, mathematics, and technology. Journal of Science Education and Technology, 15(3-4). https://doi.org/10.1007/s10956-006-9014-6

39. Ojediran, I. A. (2016). Philosophical Relevance of Physics Teacher Education Curricula in SouthWestern Nigerian Universities to Senior Secondary School Physics Curriculum. Journal of Education \& Social Policy, 3(2), 128-134.

40. Okwuoyibo Nwachukwu, C. (2012). Revisiting science education and national development: Nigerian situation and the way forward. In Arabian Journal of Business and Management Review (Vol. 1, Issue 10).

41. Olufunke, B. T. (2012). Effect of Availability and Utilization of Physics Laboratory Equipment on Students' Academic Achievement in Senior Secondary School Physics. World Journal of Education, 2(5). https://doi.org/10.5430/wje.v2n5p1

42. Onah, D. U., \& Ugwu, E. I. (2010). Factors which predict performance in secondary school physics in Ebonyi north educational zone of Ebonyi State, Nigeria. Pelagia Research Library Advances in Applied Science Research, 1(3), 255-258. www.pelagiaresearchlibrary.com

43. Prata, M. J., Festas, I., Oliveira, A. L., \& Veiga, F. (2019). The Impact of a Cooperative Method Embedded in a Writing Strategy Instructional Program on Student Engagement in School. Revista de Psicodidactica, 24(2). https://doi.org/10.1016/j.psicod.2018.11.003

44. Qablan, F., Şahin, M., \& Hashim, H. (2019). Critical Thinking in Education: The Case in Palestine. Turquoise International Journal of Educational Research and Social Studies, 1(1).

45. S. O. Daramola, \& Esther. O. Omosewo. (2012). An Appraisal of the New Nigerian Senior Secondary School Physics Curriculum. Journal of Education and Practice, 3(8), 191-195.

46. Sa'adu Matazu, D. S., \& Julius, E. (2018). Influence of Attitude, Cooperative and Inquiry Instructional Strategies on the Academic Performance of Students in Basic Science and Mathematics in Katsina, Nigeria. International Journal of Scientific Research and Management, 6(06). https://doi.org/10.18535/ijsrm/v6i6.el09

47. Salmiza, S. (2014). Malaysian students' motivation towards Physics learning. European Journal of Science and Mathematics Education, 2(4).

48. Sambo, M. H., Kukwi, I. J., A, M. M., \& Eggari, S. O. (2014). Comparative Analysis of Students' Interest in Basic Science Curriculum in Nasarawa State-Nigeria. Journal of Education and Practice, 4(29), 84-91.

49. Santyasa, I. W., Rapi, N. K., \& Sara, I. W. W. (2020). Project-based learning and academic procrastination of students in learning physics. International Journal of Instruction, 13(1). https://doi.org/10.29333/iji.2020.13132a

50. Segun Mobolaji, O., Olayemi Motunrayo, D., \& Funmilayo Justina, B. (2017). Assessment of Implementation of Physics Curriculum in Public Secondary Schools in Ekiti State. Journal of Scientific and Engineering Research, 4(8), 45-49. www.jsaer.com

51. Uchenna. S. Mbamara, \& Patrick. E. Eya. (2015). Causes of Low Enrollment of Physics as a Subject of Study by Secondary School Students in Nigeria: A Descriptive Survey. International Journal of Scientific Research in Education, 8(8), 127-149. 
52. Ukoh, E. E., \& Onifade, S. A. (2020). Pre-lesson assignments and formative assessment strategies with interactive invention instruction on low achievers in physics. Momentum: Physics Education Journal. https://doi.org/10.21067/mpej.v4i1.3846

53. Umar, U. S., \& Samuel, R. I. (2018). School Location as Correlate of Students' Achievement in Basic Science. International Journal of Innovative Education Research, 6(3), 14-18. www.seahipaj.org

54. Yunusa, U., Abdulwahid, U., \& Mustapha Adullahi, I. (2014). Effect of Cooperative Instructional Strategy on Interest and Achievement in Biology among Low-Achieving Senior Secondary School Students in Niger State, Nigeria. European Journal of Educational Sciences, 1(2). 